\title{
General Discussion to papers of Dr W. G. Rama Rao and Mr E. Griffiths
}

Professor Paeslack (Chairman). Both papers are open for discussion.

DR Dollfus (France). I think that what we've seen is extremely interesting and especially the end of your paper where you were discussing the situations in different countries. I think that there must be an effort to assess the real needs of countries which are undeveloped or underdeveloped. This is going to be one of our major tasks in the future as well as the United Nations because we must help these people as much as we can. There are two ways of helping, one is as they are doing in Montreal in Canada and as they are doing in Paris in France in mending wheelchairs and making them useful again and sending them to countries which need them. The other way is also teaching the people how to use simple technical aids and this is sometimes overlooked. The other thing is that paraplegics and tetraplegics should be housed, as you rightly said, individually and in accordance with each country's needs. I think that one should also consider the focus system in Sweden and also the Tenten Sinclair system in Canada in Winnipeg where the people come in to these homes which are adapted so they can learn to live as much as possible alone and get out of them into the general population as independent as possible.

DR MEINECKe (Germany). First of all I would like to congratulate my friend Ellis Griffiths for his excellent presentation. The only thing which was to me a little bit difficult to understand was his speaking so fastly that I probably didn't get everything, and, therefore, I probably have to apologise for my questions. I would like to know what experience you have with regard to the physiological and social points with people living in that area permanently, because often one is told you shouldn't set up a ghetto, and that's one of the main obstacles we have.

Sir LudWig GutTMANN (G.B.). These two papers are complimentary and have shown clearly that it is not just the treatment we are giving to the paralysed people but unless there is an efficient social service, our work is pretty useless, and that is what we have to deal with particularly in the developing countries. It is much more important to impress on the authorities to develop a social service for the paralysed and other diseased people. I have visited so many countries and what Dr Rao has shown in his horrible pictures I have seen in all these developing countries. One really must see it to believe it. In Addis Ababa, I went to the nearby leprosy colony. People there lived amongst tombstones, and there I saw a girl of 18 , a polio with terrible sores lying amongst leprosy people. This shows us the terrible situation which is still prevailing. I was very interested in that drawing of the palm trees demonstrating the cause of serious falls, and I'd like to suggest that you could be a missionary in this area by teaching farmers to prevent spinal injuries by training monkeys to do the work for them. I told you before about my experience in Malaysia in Kotaburo, where the Japanese started the campaign against the British. This is exactly the type of area that you described in your country. There I saw for the first time how the farmers have trained monkeys, small monkeys. The monkey was kept on a long lead and the farmer whistled once whereupon the little animal climbed very quietly up until he was amongst the leaves, then the man whistled twice and that animal took a coconut fruit, and turned it with his little hands until it fell down. Now what can be done in Malaysia, I think you may do in India too. That is at least one type of preventive medicine of spinal cord injuries.

MR GRIFFITHS. If I may answer the questions. Firstly from Dr Meinecke. I'm sorry, Fred, I was trying to compress too much material in too short a time. I apologise if I was going too quickly. We have not formed a ghetto, the number of patients we have in the State is a very small proportion that are resident. Of those who are resident, some use it as a half-way house, they will be there 2 to 6 months and then go to live in their homes in the city. We still have a hard core of those who have perhaps a major disability 
and no relatives, no family and no possibility of living alone and these are the ones that are permanent. The vast majority to live in their homes with adaptations of the homes done and these are what we aim at. I would say that we have no more than between 5 or 10 per cent of those even of tetraplegic who are in the hostel. There are very few in comparison to the numbers involved. This is our objective still, what we aim at. Can I also make one comment on the wheelchair repair. The sophisticated chrome-plated wheelchair would not last $2 \mathrm{~min}$ in an Indian village. You'd want a big sturdy 3-wheeler, a wooden frame, a big hard solid frame not collapsible to take the rough streets, and the same applies to calipers of limbs. Do you agree, Dr Rao, that we don't want sophisticated Western equipment? It is the basic hard-wearing simple equipment that can be repaired in the village, the local blacksmith can weld it if needs be.

DR RAO (India). I agree with what you said but I want to make one comment about the Perth Quadriplegic Centre. We have been trying for a very long time in Bombay at least to have a Centre like that. I don't think it's a practical situation for us people and much more so, these Centres seem to be concentrating in the cities that are already overpopulated and to reach these Centres from the villages is more difficult for us people. One must aim not to keep these people in Centres. They tend to have a situation like this amongst the blind and it was a very difficult situation to work with, those people when they are fully trained go back to society, they stayed there and the Unions came into it and they gave us a lot of trouble.

PROFESSOR WEISS (Poland). I would like to make a few comments to both of those papers. I believe there does not exist a more tragic situation for the doctor than when he discharges a patient and then can do nothing for his future social life. I am convinced that all of us should fight in the same way to create facilities for rehabilitation and then social vocational insurance to follow. Sir Ludwig tried and Sir George Bedbrook followed. In my own country, as well as in countries which I have visited during my W.H.O. consultant work in the far east, I understand that a follow-up should be adjusted to social conditions and traditions in the country. For instance, in India exists a very strong family relationship and family responsibility, and the family would get a very simple support. They can care for their own men with only very simple adjustments to their country conditions. I believe that in such countries cooperatives are one of the solutions. Such cooperatives exist in my country as completely private institutions. Thanks to them we have built a residential vocational area for 200 paralysed workers which is not at all an asylum but a factory with boarding facilities for a wheelchair worker. This worker has only one difference because he's using a wheelchair and he needs to get no architectural barriers within this facility. This is quite a simple approach and now we approach a big factory in a stage of investment, because shortage of manpower in my country exists to build sheltered apartment facilities including boarding facilities to house the workers. There are many instances in highly developed countries where disabled workers are much better than normal workers. We know in my country that sick leave among severely handicapped is half of normal people's sick leave, as the statistics show. I have created within Warsaw a 20-bed apartment on a ground floor where everybody lives, and I must tell you how reluctant Polish society is to accept a person in a wheelchair amongst them. Only ex-prisoners have accepted my paralysed. At the beginning everybody refused. Now it is OK because we train them and we have some lectures for them and now they are completely implanted in society. The same situation exists in many countries in the world and I believe that our fighting for solving social and vocational life for them is the answer for us as the judges because we saved their lives. We have saved $a$ and now $b$ should be saved.

DR RAVICHANDRAN (G.B.). I would like just to mention briefly that we organised for next year in Tunisia with the help of Professor Glessop and the help of United Nations, W.H.O. Expo, a workshop symposium on the transfer of technology to developing countries in order to try to establish an international policy for simple and strong assistive devices and try to avoid the custom barriers and maybe make a group of industries in order to help the people. 